MARCIA C. INHORN

\title{
MAKING MUSLIM BABIES: IVF AND GAMETE DONATION IN SUNNI VERSUS SHI'A ISLAM
}

\begin{abstract}
Medical anthropological research on science, biotechnology, and religion has focused on the "local moral worlds" of men and women as they make difficult decisions regarding their health and the beginnings and endings of human life. This paper focuses on the local moral worlds of infertile Muslims as they attempt to make, in the religiously correct fashion, Muslim babies at in vitro fertilization (IVF) clinics in Egypt and Lebanon. As early as 1980, authoritative fatwas issued from Egypt's famed Al-Azhar University suggested that IVF and similar technologies are permissible as long as they do not involve any form of third-party donation (of sperm, eggs, embryos, or uteruses). Since the late 1990s, however, divergences in opinion over third-party gamete donation have occurred between Sunni and Shi'ite Muslims, with Iran's leading ayatollah permitting gamete donation under certain conditions. This Iranian fatwa has had profound implications for the country of Lebanon, where a Shi'ite majority also seeks IVF services. Based on three periods of ethnographic research in Egyptian and Lebanese IVF clinics, this paper explores official and unofficial religious discourses surrounding the practice of IVF and thirdparty donation in the Muslim world, as well as the gender implications of gamete donation for Muslim marriages.
\end{abstract}

KEY WORDS: In vitro fertilization, gamete donation, Islam, medical anthropology, Middle East

\section{INTRODUCTION: MEDICAL ANTHROPOLOGY AND SCIENCE} AND TECHNOLOGY STUDIES

In recent years, medical anthropologists have been turning their ethnographic attention to issues of science and technology, including how science is produced, where it is produced, by whom, and when. Anthropologists have also highlighted how scientific and technological advancements spread around the world, gradually being incorporated into the lives of ordinary people in many global sites. In order to document the production and reproduction of new scientific and technological discoveries, medical anthropologists have begun to take their ethnographic research projects into previously unexplored terrains, including hospitals, scientific research laboratories, clinical consultation rooms, and other "behind the scenes" places where the culture of science and technology is perhaps best revealed. Furthermore, most of the medical anthropologists working in this field have documented the ways in which the scientific and the divine seem to have Culture, Medicine and Psychiatry 30: 427-450, 2006.

(C) 2006 Springer Science+Business Media, Inc.

DOI: $10.1007 /$ s11013-006-9027-x 
intermingled, not only among the patients who turn to religious theodicies to make sense of their suffering, but also among the scientists and clinicians who deliver medical services and attempt to offer patients hope. These recent medical anthropological efforts to document the intersections of science, technology, and religion are clearly reflected in the theme of the 2004 annual meeting of the American Anthropological Association: "Magic, Science, and Religion." Furthermore, this special issue of Culture, Medicine and Psychiatry reflects the ongoing importance of religion to science, medicine, and biotechnology, including in the Muslim world.

Medical anthropology has much to offer to discussions of science, medicine, and religion, as demonstrated in a number of award-winning books on these subjects. To take but a few recent examples, in Testing Women, Testing the Fetus: The Social Impact of Amniocentesis in America, medical anthropologist Rayna Rapp (1999) reveals the efforts of more than ten years' worth of extensive ethnographic research conducted at New York City hospitals, genetic counseling and testing centers, and genetics laboratories themselves. Her book focuses on the difficult decision-making of pregnant women from multiple ethnic, religious, and economic backgrounds, who are asked by clinicians and advised by genetic counselors to undergo amniocentesis in order to detect genetic anomalies in their fetuses. Although the scientific field of genetics is burgeoning with excitement, Rapp's intent in Testing Women, Testing the Fetus is to show how women who are expected to use new genetic tests during pregnancy are put in the difficult position of being "moral pioneers:" namely, they are forced to make often heartwrenching moral decisions about what constitutes an acceptable human life.

Whereas Rapp's book focuses on decisions about bringing life into the world, a book by medical anthropologist Margaret Lock asks us to consider decisions about ending lives considered "brain dead." Twice Dead: Organ Transplants and the Reinvention of Death, Lock's (2002) ethnography, examines the history of organ transplantation in North America over the past 20 years. Scientific advancements in transplant technology have made it possible for North American surgeons to perform thousands of transplants each year. In the majority of these cases, individuals diagnosed as "brain dead" are the source of the organs, without which transplants could not take place. Lock asks her readers to consider what is meant by "brain death," and how it might be viewed differently in another culture, namely, Japan. Despite the availability of the necessary technology and expertise, Japanese society has not accepted the notion of brain death as a sufficient criterion of death, following a well-informed but heated public debate on the topic. Although brain death was legally recognized in Japan in 1997, it is authorized only in limited circumstances, meaning that organ transplantation 
in Japan is not widespread. Drawing on extensive interviews conducted over ten years with Intensive Care Unit (ICU) physicians, transplant surgeons, organ recipients, donor families, Japanese political activists opposed to the recognition of brain death, and members of the general public in both Japan and North America, Lock shows us that death itself is not a self-evident, biological event. Rather, it is surrounded by morally troubling cultural, medical, legal, and political dimensions.

Lock's book clearly demonstrates the degree to which medical anthropology is concerned with comparative cultural perspectives, particularly in an era of rapid globalization. Indeed, medical anthropology as a discipline can be said to focus on the "local in the global." In other words, local considerations, be they cultural, social, economic, or political, shape and sometimes curtail the way that Western-generated scientific technologies are both offered to and received by non-Western subjects. New forms of science and technology are not transferred into cultural voids when they reach places like Japan. Thus, the assumption on the part of global producer nations that new biotechnologies - as value-free, inherently beneficial medical technologies - are "immune" to culture and can thus be appropriately transferred and implemented anywhere and everywhere is subject to challenge once local formulations, perceptions, and actual consumption of these technologies are taken into consideration (Inhorn 2003a).

Indeed, the global spread of biotechnologies provides a particularly salient but little discussed example of what anthropologist Arjun Appadurai (1996) has termed a "technoscape," or the "global configuration, also ever fluid, of technology, and the fact that technology, both high and low, both mechanical and informational, now moves at high speeds across various kinds of previously impervious boundaries." Appadurai reminds us that this movement of technologies around the globe is both a deeply historical and an inherently localizing process. In other words, globalization is not enacted in a uniform manner around the world, nor is it simply culturally homogenizing - necessarily "Westernizing" or even "Americanizing" in its effects. The global is always imbued with local meaning, such that local actors, living their everyday lives at particular historical moments in particular places, mold the very form that global processes take (Freeman 2000).

This acknowledgment of the importance of locality in the global dispersion of modern biotechnologies has been a theme of much recent work in medical anthropology. Similarly, much of this anthropological concern with locality has to do with local moral systems, or what medical anthropologist/ psychiatrist Arthur Kleinman (1995) has called "local moral worlds" of pain and suffering. According to Kleinman (45), local moral worlds are "moral accounts, [which] are the commitments of social participants in a local world 
about what is at stake in everyday experience." Through an "ethnography of experience," Kleinman urges medical anthropologists to pay close attention to the moral issues that may accompany the arrival of new biotechnologies around the globe. In his recent powerful and path-breaking book, What Really Matters: Living a Moral Life amidst Uncertainty and Danger, Kleinman (2006) asks us to carefully consider what it really means to live a "moral life," particularly in the midst of life-or-death decisionmaking.

This focus on the "local moral" is found in another award-winning book on the topic of IVF. Titled Reproducing Jews: A Cultural Account of Assisted Conception in Israel, this book by medical anthropologist Susan Martha Kahn (2000; see also her article in this special issue) takes us into the often arcane world of Jewish Halakhic law, where male rabbis legislate on the appropriate uses of IVF for their followers. Kahn carefully describes how these rabbinical debates and decisions affect the actual practice of Israeli IVF. For example, third-party donation of gametes, including sperm donation, is allowed, since Jewishness is seen to be conferred through the mother's side, particularly through the act of gestating and birthing the baby. However, most conservative rabbis prefer that non-Jewish donor sperm be used, to prevent adultery between a Jewish man and a Jewish woman and to prevent future genetic incest among the offspring of anonymous donors in this small, intermarrying country. Furthermore, debates have revolved around whether surrogacy should be allowed for infertile couples, using single or married surrogates. Generally speaking, single Jewish women are preferred as surrogates, both to avoid the implications of adultery for married surrogate women and to confer Jewishness through a Jewish woman's gestation of the fetus. Finally, because the Jewish state is pronatalist - with the state subsidizing up to six cycles of IVF or up to the birth of two IVF children for any given Jewish patient-rabbis have generally been permissive when it comes to single career women, as well as lesbian Jewish mothers, conceiving children through assisted conceptive means.

Kahn's fascinating and frankly funny book details the sometimes dizzying rabbinical arguments regarding morally appropriate and inappropriate reproduction. In so doing, the book bespeaks the importance of local religious moralities in the contemporary world of Israeli assisted conception. There, doctors in many clinics serving orthodox Jewish patient populations attempt to practice IVF according to the moral dictates set forth by religiously conservative rabbis. The IVF laboratories in these clinics are full of orthodox women called maschigots, who literally peer over the shoulders of laboratory technicians to make sure that the correct sperm and correct eggs 
are being united - so as not to produce a mamzer, or an illegitimate child. In her book, Kahn is explicit in stating that the American consumer model of free-market reproductive medicine has yet to take hold in Israel, with its concern over religious guidelines. Nonetheless, Israel's relative permissiveness over the use of donor gametes, surrogacy, and single and lesbian motherhood stands in stark contrast to the Muslim Middle East, including both neighboring Egypt and Lebanon, where I have conducted my own ethnographic research on IVF.

\section{IVF IN THE MUSLIM MIDDLE EAST}

With this background in mind, it is my goal in this article to take readers into the heart of the Muslim Middle East, thereby showing how the practice of IVF in Israel, the country located between Egypt and Lebanon, differs significantly from that in both of its Muslim neighbors. During more than two years of medical anthropological fieldwork in Egypt (1988-89, 1996) and Lebanon (2003), I conducted in-depth, ethnographic interviews with infertile Muslim IVF patients, both husbands and wives, now totaling nearly 500 patient couples. Furthermore, since the mid-1990s, I have focused my research on the rapid expansion of IVF technologies into this region of the Muslim world. Indeed, it is fair to assert that since the birth in 1978 of Louise Brown, the world's first test-tube baby, IVF has spread around the globe, reaching countries far from the technology-producing nations of the West. Perhaps nowhere is this globalization process more evident than in the 22 nations of the Muslim Middle East, where a private IVF industry is flourishing. As of 2003, Egypt alone (population 70 million) boasted 50 IVF centers, and the tiny country of Lebanon (population 4 million) boasted more than 15 IVF centers, one of the highest per capita concentrations in the world. These global metrics are impressive compared to the IVF technology-producing nation of Israel, where 24 IVF centers cater to a population of 6 million (Kahn 2000).

In both Egypt and Lebanon, as in other Muslim countries, nonbinding but authoritative Islamic religious proclamations called fatwas have profoundly affected the practice of IVF in ways that are not commonly seen in the West. Indeed, in the Muslim world, infertile couples are usually extremely concerned about making their test-tube babies in the religiously correct fashion. To that end, they seek out the "official" Islamic opinion on the practice of IVF in the form of a fatwa. In recent years, many such fatwas on a wide variety of reproductive health issues have been issued in Egypt and other Muslim countries (Lane and Rubinstein 1991; Zuhur 1992). But 
as we shall see in this paper, major divergences have occurred between Sunni and Shi'ite religious authorities regarding the permissibility of third-party gamete donation, with new fatwas emerging from the Shi'ite world in recent years. It is the differences between Sunni and Shi'a Islam with regard to third-party gamete donation that constitute the focus of this article.

\section{Sunni Islam and IVF}

IVF was first practiced in the Sunni Muslim world, with clinics opening in the mid-1980s in Egypt, Saudi Arabia, and Jordan, all Sunni-majority countries. The Grand Shaikh of Egypt's famed religious university, A1 Azhar, issued the first widely authoritative fatwa on medically assisted reproduction on March 23, 1980. This fatwa-issued only two years after the birth of the first IVF baby in England but a full six years before the opening of Egypt's first IVF center-has proved to be truly enduring in all its main points (Inhorn 2006a). In fact, the basic tenets of the original Al-Azhar fatwa on IVF have been upheld by other fatwas issued since 1980 and have achieved wide acceptance throughout the Sunni Muslim world. Sunni Islam, it must be emphasized, is the dominant form of Islam found in the Middle Eastern region and throughout the Muslim world. Between 80 and 90 percent of the world's Muslims are Sunni, and more than 90 percent of Egypt's citizens are Sunni Muslims, the rest being predominantly Coptic Christian.

The degree to which these official Sunni Islamic fatwas on IVF have affected the actual practices of the Middle Eastern medical profession is also quite striking. For physicians, the dominant Sunni religious opinion on IVF has been made known to the Middle Eastern medical community through the writings of Gamal I. Serour, one of three founding members of the first Egyptian IVF center and the director of Al-Azhar's International Islamic Center for Population Studies and Research. In article after article (Serour 1992, 1994, 1996; Serour and Omran 1992; Serour, El Ghar, and Mansour 1990, 1991; Serour, Aboulghar, and Mansour 1995), Serour has spelled out the main points of the Sunni Islamic position on medically assisted conception, as follows:

(1) Artificial insemination with the husband's semen is allowed, and the resulting child is the legal offspring of the couple.

(2) In vitro fertilization of an egg from the wife with the sperm of her husband followed by the transfer of the fertilized embryo(s) back to the uterus of the wife is allowed, provided that the procedure is indicated for a medical reason and is carried out by an expert physician. 
(3) No third party should intrude into the marital functions of sex and procreation, because marriage is a contract between the wife and husband during the span of their marriage. This means that a third party donor is not allowed, whether he or she is providing sperm, eggs, embryos, or a uterus. The use of a third party is tantamount to zina, or adultery.

(4) Adoption of a donor child from an illegitimate form of medically assisted conception is not allowed. The child who results from a forbidden method belongs to the mother who delivered him/her. He or she is considered to be a laqit, or an illegitimate child.

(5) If the marriage contract has come to an end because of divorce or death of the husband, medically assisted conception cannot be performed on the ex-wife even if the sperm comes from the former husband.

(6) An excess number of fertilized embryos can be preserved by cryopreservation. The frozen embryos are the property of the couple alone and may be transferred to the same wife in a successive cycle, but only during the duration of the marriage contract.

(7) Multifetal pregnancy reduction (or so-called selective abortion) is only allowed if the prospect of carrying a high-order pregnancy (i.e., twins, triplets, or more) to viability is very small. It is also allowed if the health or life of the mother is in jeopardy.

(8) All forms of surrogacy are forbidden.

(9) Establishment of sperm banks is strictly forbidden, for such a practice threatens the existence of the family and the "race" and should be prevented.

(10) The physician is the only qualified person to practice medically assisted conception in all its permitted varieties. If he performs any of the forbidden techniques, he is guilty, his earnings are forbidden, and he must be stopped from his morally illicit practice.

But to what degree are these fatwa declarations - particularly the explicit prohibition on any form of third-party donation of reproductive materials - actually followed by physicians in the Muslim world? A global survey of sperm donation among assisted reproductive technology centers in 62 countries provides some indication of the degree of convergence between official discourse and actual practice (Meirow and Schenker 1997). In all of the Muslim countries surveyed in the mid-1990s - including the Middle Eastern countries of Egypt, Iran, Kuwait, Jordan, Lebanon, Morocco, Qatar, and Turkey, as well as a number of non-Middle Eastern Muslim countries, including Indonesia, Malaysia, and Pakistan - sperm donation in 
IVF and all other forms of gamete donation were strictly prohibited. As the authors of this global survey, Meirow and Schenker (1997), state, "In many Islamic countries, where the laws of Islam are the laws of the state, donation of sperm was not practiced. AID [Artificial Insemination, Donor] is considered adultery and leads to confusion regarding the lines of genealogy, whose purity is of prime importance in Islam" (134).

In summary, in the Sunni-majority countries of the Middle East and the rest of the Sunni Muslim world, prohibitions against gamete donation have been enacted either in law or in professional medical codes of ethics. As a result, gamete donation is not legally practiced in the Sunni Muslim world, with clinics turning away (or referring to other European countries) couples who require these services. In Sunni Muslim countries such as Egypt, the thought of using donor gametes is reprehensible to most infertile Muslim (and even Christian) couples, who agree completely with the bans on thirdparty donation dictated by the religion and upheld through medical codes of ethics (Inhorn 2003b). As shown in the next section, however, the situation is changing for Shi'ite Muslims, whose leading cleric has taken a bold step in a new direction.

\section{Shi'a Islam and IVF}

For Shi'ite Muslims, attitudes toward gamete donation have changed considerably since the late 1990s. Shi'a is the minority branch of Islam found in Iran, parts of Iraq, Lebanon, Bahrain, Syria, and Saudi Arabia, as well as Afghanistan, Pakistan, and India. It has been much in the news lately because of the United States-led war in Iraq, the conflict between Lebanon and Israel, and the current tensions between the United States and Iran. Until recently, most Shi'ite religious authorities have supported the majority Sunni view: namely, they have agreed with Sunni clerics who say that thirdparty donation should be strictly prohibited.

In the late 1990s, however, the Supreme Jurisprudent of the Shi'a branch of Islam, Ayatollah Ali Hussein Khamanei, the handpicked successor to Iran's Ayatollah Khomeini, issued a fatwa effectively permitting donor technologies to be used. This fatwa has proved to be very significant for those Shi'a who follow the lead of Ayatollah Khamanei in Iran. This would include Lebanon's Hizbullah leaders, who consider Ayatollah Khamanei to be their marja' taqlid, or spiritual reference (literally, source of emulation).

With regard to egg donation, Ayatollah Khamanei stated in his initial fatwa that egg donation "is not in and of itself legally forbidden." But he stated that both the egg donor and the infertile mother must abide by the religious codes regarding parenting. Thus, the child of the egg donor has the 
right to inherit from her, as the infertile woman who received the eggs is considered to be like an adoptive mother.

With regard to sperm donation, Ayatollah Khamanei said in his original fatwa that the baby born of sperm donation will follow the name of the infertile father rather than the sperm donor. However, as with egg donation, the donor child can only inherit from his biological father, the sperm donor, since the infertile father is considered to be like an adoptive father.

The situation for Shi'ite Muslims is actually much more complicated than this, however, given two Shi'ite religious practices called ijtihad and $m u t^{c} a$. Unlike Sunni Muslim scholars who are scripturally based in their thinking, Shi'ite religious authorities give precedence to a form of individual religious reasoning known as ijtihad. Through the use of ${ }^{c} a q l$, or intellectual reasoning, various Shi'ite ulama have come to their own conclusions regarding the rightness or wrongness of gamete donation. Some Shi'ite clerics continue to prohibit gamete donation for their followers, while others have allowed it under certain conditions. As many scholars of Shi'a have noted (Cole 2002; Tober 2004), the practice of ijtihad has allowed a certain flexibility and pragmatism toward new technological developments, including IVF and a number of other new medical technologies (e.g., contraception, organ transplants, transgender surgery). Furthermore, ijtihad has ultimately led to great heterogeneity of opinion and practice within the Shi'ite community.

Additionally, Shi'a Islam allows a form of temporary marriage called $m u t^{c} a$ (also called sigheh in Iran), which is not recognized by Sunni religious authorities (Zuhur 1992). In Shi'a Islam, mut ${ }^{\mathrm{c} a}$ is a union between an unmarried Muslim woman and a married or unmarried Muslim man, which is contracted for a fixed time period in return for a set amount of money. It is practiced in Iran (Haeri 1989), as well as in other parts of the Shi'ite world. In the past, middle-aged and older women who were divorced or widowed often engaged in mut ${ }^{\mathrm{c}}$ a marriages for financial support. In Iran, following the loss of men during the devastating, eight-year Iran-Iraq war, former Iranian President Rafsanjani recommended mut ${ }^{\mathrm{c}} \mathrm{a}$ as a means of protecting the large numbers of single or widowed women who had no other source of income. For Shi'ite men, mut ${ }^{\mathrm{c}}$ a marriages could be contracted while traveling, or as a way of achieving marital variety and sexual pleasure (Haeri 1989). Since the arrival of donor technologies, however, mut ${ }^{c}$ a has also been invoked to make egg donation legal within the parameters of marriage.

Within this context of ijtihad and mut ${ }^{\mathrm{c}} \mathrm{a}$, Shi'a religious authorities who now accept the idea of donation, but are strict in their interpretation of how donation should be practiced, argue that 
(1) when a couple needs a donor, they should go to a Shi'ite religious court, where a decision can be made on a case-by-case basis;

(2) there should be a determination about which religious "reference" (i.e., source of spiritual emulation) the infertile couple follows;

(3) the decision should be made in the presence of witnesses, the IVF doctor, and with the agreement of both parties (the infertile couple and the donor);

(4) the husband should do a mut ${ }^{\mathrm{c}}$ a marriage with the egg donor for the period of time in which the whole procedure (egg retrieval to embryo transfer) is taking place, because polygyny is legal in Islam and avoids the implications of zina, or adultery;

(5) but because a married Shi'ite Muslim woman cannot marry another man other than her husband (since polyandry is illegal in Islam), she cannot do a mut ${ }^{c}$ a marriage with a sperm donor. Technically, the child born of a sperm donor would be a laqit, or out-of-wedlock child, without a family name and without a father. Thus, in theory, only widowed or otherwise single women should be able to accept donor sperm, in order to avoid the implications of zina. However, in the Muslim countries, single motherhood of a donor child is unlikely to be socially acceptable (Inhorn 1996; Zuhur 1992).

Be that as it may, divergent gamete donation practices are beginning to emerge in the Shi'ite Muslim world, as religious authorities come to their own conclusions about third-party donation. Among Shi'ite religious scholars, the major disagreements, or religious "sticking points," revolve around the following set of issues:

(1) whether sperm donation should be allowed at all;

(2) whether the child should follow the name of the infertile father or the sperm donor;

(3) whether the child should inherit from the infertile father or the sperm donor;

(4) whether donor children and their "social" parents are related at all, and, if not, whether they could potentially marry each other, which has implications for proper comportment in domestic life (e.g., bathing, veiling, etc. $)^{1}$

(5) whether donation is permissible at all if the donors are anonymous;

(6) whether a financial transaction should be allowed between gamete donors and recipients;

(7) whether the husband of an infertile woman needs to do a temporary mut ${ }^{\mathrm{c}}$ a marriage with the egg donor, then divorce her after the embryo transfer (48 to 72 hours later), in order to avoid zina. For 
his part, Khamanei clearly stipulates that mut ${ }^{\mathrm{c}}$ a marriage is not required, for he believes that zina requires the physical act of intercourse (Clarke 2006); and

(8) whether the wife of an infertile husband can temporarily divorce her infertile husband, remarrying him after accepting sperm from a donor (Tremayne, personal communication, 5/5/06).

These disagreements of opinion have played out in interesting ways. As shown in anthropologist Morgan Clarke's (2006) recent research on the Shi'ite religious discourses surrounding gamete donation, many Shi'ite ulama do not agree with Khamanei's permissive fatwa on donor technologies, because they do not regard him as a brilliant legal thinker. For example, Ayatollah Muhammad Husayn Fadlallah, Lebanon's most prominent Shi'ite religious figure, does not agree with Ayatollah Khamanei's permission of sperm donation, although he agrees with the permission of egg donation. Neither of them requires the use of mut ${ }^{\mathrm{c}}$ a marriages to solve the zina issue (Clarke 2006).

Ayatollah Fadlallah's positions opposing sperm donation but supporting egg donation square with the dominant religious discourse in Iran. There, the religious rulings regarding gamete donation have evolved quickly, with sperm donation now effectively banned (Soraya Tremayne, personal communication, 23 July 2004, 31 July 2004). ${ }^{2}$ Namely, a law on gamete donation passed in 2003 in the Iranian parliament (majlis) and approved by the Guardian Council (i.e., a religious "watchdog" body that endorses every bill before it becomes law) has restricted gamete donation to married persons. Even though the law is brief (less than one page), it states clearly and succinctly who can and cannot donate and receive gametes. Egg donation is allowed, as long as the husband marries the egg donor temporarily - thereby ensuring that all three parties are married. Sperm donation, on the other hand, is legally forbidden, because a sperm donor cannot temporarily marry an already married woman whose husband is infertile. Quite interestingly, however, embryo donation - which involves both sperm and egg from another couple - is allowed in order to overcome both male and female infertility. Because an embryo comes from a married couple and is given to another married couple, it is considered hallal, or religiously permissible.

The social and biological implications of embryo donation are quite interesting. For Iranian couples unable to produce a child because of male infertility, embryo donation allows them to bypass the problem of the husband's weak (or absent) sperm. However, embryo donation does not allow a presumably fertile wife of an infertile husband to contribute her own ova, in effect severing her biological ties to the donor child. Furthermore, 
and most strikingly, embryos donated from another married couple involve both egg and sperm donation. Even though direct sperm donation is bypassed via the injection of another man's sperm into the wife's womb/ova, embryo donation still disrupts male paternity and involves the acceptance by an already married woman of another man's (and woman's) gametes. Moreover, a woman's acceptance of another woman's egg is effectively like gestational surrogacy, which is strictly prohibited in Sunni Islam. Indeed, in recent months, cases of surrogate motherhood have occurred in Iran, despite the lack of firm legislation regarding this practice.

Whether these problematic complications of embryo donation have been carefully thought through by the religious and legal authorities in Iran is unclear. Based on her path-breaking research carried out at Iranian IVF clinics, anthropologist Soraya Tremayne (2005, 2006) notes, "My first and possibly superficial interpretation at this stage can only be that the moral, ethical and legal aspects of the whole matter have not yet been thought through and the consequences dawned on either the doctors and legislators, or on people themselves. It seems to me that ethics will follow, rather than lead the issue. These operations have been in place only for the past ten years ... and the cases are too new to cause problems as yet" (personal communication, 23 July 2004).

It is interesting to note that many Shi'ite religious leaders both inside and outside of Iran do not agree with the relative Iranian "permissiveness" vis-à-vis donor technologies; instead, they abide by the dominant Sunni Muslim ban on all forms of third-party donation. For example, I recently attended a two-day conference in Tehran, Iran, on "Gamete and Embryo Donation," sponsored by the Avesina Research Institute in association with the Law and Political Science Faculty of the University of Tehran. ${ }^{3}$ The conference provided a fascinating example of "ijtihad in action," with some ulama, dressed in their stately robes and turbans (black for the sayyids, or descendants of the Prophet Muhammad), arguing against the moral permissibility of embryo and gamete donation. The disagreements generated in public between "pro" and "con" ulama were also debated in the more private recesses of the conference. For example, a Shi'ite shari'a judge from Bahrain, who was staying at our guest residence, took great pains to describe to me his opposition to all forms of gamete donation. To prove this point, he provided me with a copy of his book on Islamic personal status law, which had been translated into English and which supported his antigamete donation position based on evidence from the traditional Islamic scriptures. According to him, Iranian clergy, who speak Farsi rather than Arabic, are not as familiar with the original Islamic scriptures (in Arabic) that demonstrate the immorality of third-party donation. Thus, in his view, 
some Iranian clergy are "innovating" in ways that are religiously unacceptable, and that are at odds with the rest of the Muslim world.

A case in point: ayatollahs Ali al-Sistani and Muhammad Sa'id al-Tabataba'i al-Hakim, both Shi'ite religious authorities in Iraq, advise caution against third-party donation practices, viewing them as largely unacceptable (Clarke 2006). Indeed, Ayatollah al-Sistani's son, Muhammad Rida Al-Sistani, has devoted an entire volume of richly documented legal analysis to this debate, providing "an invaluable resource for other scholars" (26). According to Clarke, "Sistani's work, while perhaps posing more questions than clear answers, opens up for other scholars a fascinating window into this area of Shi'ite jurisprudential debate, at a time when the Western media are just waking up to the vibrant engagement Shi'ite scholars have had with other such new technologies" (26).

Indeed, the degree to which some Shi'ite clergy are "pushing the envelope" in the realm of reproductive science and technology is quite remarkable. At the recent gamete donation conference in Iran, some Iranian clergy and physicians present advocated for future laws permitting all forms of donation as well as surrogacy. Once passed into law, gamete donation of all kinds will be difficult to stop. Meanwhile, in the absence of formal legislation, some IVF physicians in Tehran - as well as in Shi'ite-dominant Lebanon, which is closely following the Iranian lead-are using the legal vacuum and the original "permissive" fatwa of Ayatollah Khamanei to practice all forms of gamete donation among their desperate infertile patients. As noted by Clarke (2006) for Lebanon, "Doctors keep Khamanei's fatwa collection on the shelves of their surgeries to demonstrate the permissibility of such procedures to skeptical Muslim patients; and many such patients have profited from it to undertake donor sperm and egg procedures, even surrogacy arrangements, with a clear conscience" (26).

\section{MUSLIM PATIENT OPPOSITION TO DONATION}

Although donor law and practice are headed in interesting new directions in both Iran and Lebanon, it must be reiterated that the vast majority of Muslims, both Shi'ite and Sunni, do not accept the idea of third-party gamete donation. Why are they opposed to donation?

In the hundreds of interviews that I have conducted since 1996 in Egypt (with Sunni Muslims) and Lebanon (with both Sunni and Shi'ite Muslims), the majority of infertile couples were clear that donation is haram, or forbidden by the religion (Inhorn 2006b). Patient concerns revolve around three sets of related issues: (1) the moral implications of third-party 
donation for marriage, (2) the potential for incest, and (3) the moral implications of donation for kinship and family life.

With regard to marriage, Islam is a religion that can be said to privilege - even mandate - heterosexual marital relations. As is made clear in the original Al-Azhar fatwa, reproduction outside of marriage is considered zina, or adultery, which is strictly forbidden in Islam.

Although third-party donation does not involve the sexual "body contact" of adulterous relations, or presumably the desire to engage in an extramarital affair, it is nonetheless considered by most Islamic religious scholars to be a form of adultery, by virtue of introducing a third party into the sacred dyad of husband and wife. It is the very fact that another man's sperm or another woman's eggs enter a place where they do not belong that makes donation of any kind inherently wrong and threatening to the marital bond.

The other aspect of third-party donation that troubles marriage is the potential for incest among the offspring of unknown donors. Moral concerns have been raised about the potential for a single anonymous donor's offspring to meet and marry each other, thereby undertaking an incestuous union of half-siblings.

The final moral concern voiced by Muslim IVF patients is that third-party donation confuses issues of kinship, descent, and inheritance. As with marriage, Islam is a religion that can be said to privilege - even mandate-biological inheritance. Preserving the "origins" of each child - meaning its relationship to a known biological mother and father-is considered not only an ideal in Islam, but a moral imperative. The problem with third-party donation, therefore, is that it destroys a child's lineage, which is immoral in addition to being psychologically devastating.

Muslim IVF patients use the term "mixture of relations" to describe this untoward outcome. Such a mixture of relations, or the literal confusion of lines of descent introduced by third-party donation, is described as being very "dangerous," "forbidden," "against nature," "against God"-in a word, haram, or morally unacceptable. It is argued that donation, by allowing a "stranger to enter the family," confuses lines of descent in patrilineal Islamic societies. For men in particular, ensuring paternity and the "purity" of lineage through "known fathers" is of paramount concern (Inhorn 2006b). As one Sunni Muslim man, a high school biology teacher, summarized the problem:

The most important thing is that we are Muslims. If there is faith in carrying out this operation using sperm from the husband and ova from the wife, then this is okay. We cannot accept what happens in the West. We heard some women "hire the womb" of another woman, or take sperm. According to our religion, this is called 
ikhtilat in-nasab, "mixing relations." We consider it some kind of zina, prostitution. Because there are many hadiths from the Prophet Muhammad that confirm this. If you put your sperm in another woman besides your wife, you go to hell. This is adultery. There is a hadith on adultery. "If you put your sperm in another woman other than your wife, you are going to commit a sin." People asked the Prophet, "How?" He said, "If you put it in your wife, you are going to be rewarded from Allah." They said, "Yes." He told them, "But this is also the case if you put it in the wrong womb. You are going to have punishment."

In addition to the consequences of mixed bloodlines and adultery, bringing such donor children into the world is considered unfair to the children themselves, who would never be treated with the love and concern parents feel for their "real" children. Such a child could only be viewed as a bastard - an ibn haram, literally "son of sin." Thus, a child of third-party donation starts life off as an "illegal" child. The child is deemed illegitimate and stigmatized even in the eyes of his or her own parents, who will therefore lack the appropriate parental sentiments (Inhorn 2006b). As one Sunni Muslim IVF patient stated:

My baby must be mine, and from my husband. This is logical. A mother will never feel this is her child if it is from another [man's] donated sperm or ova. It's only natural. Everything must occur naturally. If the child is from the father and mother, they will feel this is actually our baby. If not, we'll not be a family. The feeling of the baby, and our feelings. You will feel like you're acting, making a movie, living a life that's not true. This is our feeling. Of course, people take babies [through adoption], but this is not so common here in Egypt. We don't even want to think about this point! We are making our trial [of IVF] and hoping God will help us.

Indeed, the firm conviction that parenthood of a donor child is an impossibility is clearly linked to the legal and cultural prohibitions against adoption throughout the Muslim world. The Islamic scriptures, including the Qur'an, encourage the kind fostering of orphans but do not allow legal adoption as it is known in the West, whereby a child takes its adoptive parents' surname and is treated as one's own child (Inhorn 1996; Sonbol 1995; Zuhur 1992). In the Muslim Middle East, few IVF patients, either Sunni or Shi'ite, will contemplate adoption, stating with conviction that it "against the religion" and that the adopted child "won't be my own son" (Inhorn 2006b). Even though legal adoption is practiced in Iran - with the child receiving a birth certificate in the adoptive couple's name after a six-month period of adjustment - the social and cultural resistances to adoption remain strong in that country, making this a "last resort" for infertile Iranian couples (Janet Heindl, personal communication, 8 July 2004; Tober 2004).

Nonetheless, Iran's acceptance of adoption has clearly paved the way for gamete donation, with Ayatollah Khamanei's initial fatwa deeming the 
infertile couple to be like adoptive parents. Indeed, Iran's clearly adventurous path regarding both adoption and donation is leading to social transformations in other parts of the Shi'ite Middle East, in ways described in the following section.

\section{MARRIAGE AND GENDER RELATIONS}

In considering infertility and IVF in the Muslim world, it is important to ask: What happens to infertile Middle Eastern Muslim couples who are not allowed to adopt and who do not accept the use of donor gametes? In the absence of adoption and gamete donation, infertile Muslim couples have no choice but to turn to IVF and other assisted reproductive technologies to solve their infertility problems using their own gametes.

In the Middle Eastern Muslim world, marriage is highly valued, and nearly all adults marry if possible in most Middle Eastern countries (Population Reference Bureau 2004; Zuhur 1992). Middle Eastern societies are also pronatalist - they highly value children for numerous reasons and expect all marriages to produce them (Inhorn 1996). Thus, the notion of a married couple living happily without children is unthinkable. Children are desired from the beginning of marriage in most cases, and are usually loved and cherished once they are born.

As a result, childless couples are often under tremendous social pressure to conceive. In the Muslim world, infertile women often live in fear that their marriages will "collapse," for Islamic personal status laws consider a wife's barrenness to be a major ground for divorce. Although Islam also allows women to divorce if male infertility can be proven, a woman's initiation of divorce continues to be so stigmatizing that women rarely choose this option unless their marriages are truly unbearable (Inhorn 1996). Instead, they often "cover" for their infertile husbands, accepting the social responsibility for the infertility and diffusing the embarrassment of their husbands' reproductive emasculation (Inhorn 2003b, 2004).

The emergence of the revolutionary new IVF technology called intracytoplasmic sperm injection (ICSI), however, has ironically increased the potential for divorce in the Muslim Middle East. Namely, with ICSI, infertile men with very poor sperm profiles - even azoospermia, or lack of sperm in the ejaculate - are now able to produce "biological" children of their own. As long as a single viable spermatozoon can be retrieved from a man's body, including through painful testicular aspirations and biopsies, this spermatozoon can be injected directly into the ovum under a highpowered microscope. What ICSI requires, then, is high-quality ova, despite 
low-quality sperm. However, the wives of many of these men, who have "stood by" their infertile husbands for years, even decades in some cases, may have grown too old to produce viable ova for the ICSI procedure. In the absence of adoption or of any kind of egg donation, infertile Muslim couples with a reproductively "elderly" wife face four difficult options: (1) to remain together permanently without children; (2) to legally foster an orphan, which is rarely viewed as an acceptable option; (3) to remain together in a polygynous marriage, which is rarely viewed as an acceptable option by women themselves; or (4) to divorce so that the husband can have children with a younger wife.

In my research in Egypt and Lebanon, the first option has proven to be the most common - namely, infertile husbands and their 40-something wives often love each other deeply, and remain together in long-term marriages without producing any children. Thus, divorce is not the immediate consequence of infertility that it is stereotypically portrayed to be. Because of the Sunni Islamic restrictions on the use of donor eggs, however, as well as lack of acceptance of this option among some segments of the Shi'ite population, at least some Muslim men are choosing to divorce or take a second wife, believing that their own reproductive destinies lie with younger, more fertile women.

That being said, in the Shi'ite Muslim world, including in Iran and Lebanon, at least some Shi'ite couples are beginning to receive both donor gametes and donor embryos, ${ }^{4}$ as well as donating their gametes to other infertile couples. For infertile Shi'ite couples who accept the idea of thirdparty donation - as well as for Ayatollah Khamanei, who originally introduced the idea of donation to the Muslim world - the introduction of donor technologies has been described as a "marriage savior," helping to avoid the "marital and psychological disputes" that may arise if the couple's case is otherwise untreatable. Such disputes are clearly dramatized in the popular Iranian film Laila, which documents the painful separation of an otherwise happily married but infertile couple, and which was released in the mid-1990s before the Khamanei fatwa permitted such marriages to be saved through the use of donor technologies.

In Iran today, donor egg and donor embryo programs have been set up at most IVF clinics. Donor eggs come from three sources: other IVF patients, relatives, ${ }^{5}$ and unmarried women who agree to participate as egg donors in one-day mut ${ }^{\mathrm{c}}$ a marriages for a fee. Such marriages only require a witness and are not officially registered; thus, they take place in confidence in the back rooms of IVF clinics. Indeed, donors who wish to remain anonymous enter these mut ${ }^{\mathrm{c}}$ a marriages only by written agreement, without ever meeting the recipients of their eggs or their temporary husbands. They 
receive their money following egg harvesting (usually about U.S. \$550), provide no personal information about themselves to the recipient couple, receive no information about the recipient couple, and "go about their business" (Soraya Tremayne, personal communication, 31 July 2004). In short, egg donation - as well as embryo donation from other couples - is largely a financial transaction in Iran, with very little regulation or control over who donates or how donation is enacted.

The same is not true for the receiving of embryos. According to Tremayne, the recent law in Iran specifies clearly that couples desiring an embryo as a result of infertility must apply in writing to a court in order to receive permission for embryo transfer. The law specifies that the couple must be morally sound and suitable as parents and must be Iranian citizens, much like the law governing adoption in Iran (Janet Heindl, personal communication, 8 July 2004). Still, the donor embryo law is so new that most IVF clinics in Iran do not yet own a copy of the legislation and are not necessarily abiding by the legal requirements for donor embryo transfer at their clinics. If the husband is infertile, the couple simply receives another couple's embryos, with most donor couples choosing to remain anonymous. As Tremayne (31 July 2004) states,

I did not get the impression that people desperate to have a child thought very far about the issues of kinship and family relations. As far as I could see, the donation is considered more a financial transaction than a donation/gift, and once you have paid the couple to buy their embryo, or paid the temporary wife for her egg, they have no further claims on you and this is the end of the story. The forms filled by the donors leave it to them to decide whether they want to give their name or not.

In Lebanon where I have conducted my own research, the situation is very similar, despite the lack of a national law governing any aspect of IVF or third-party donation. ${ }^{6}$ At Lebanese IVF clinics providing donor technologies, some of the donors are other IVF patients (mostly Shi'ite Muslims who accept the idea of donation), some are friends or relatives (including egg-donor sisters), and some are anonymous donors, who provide their ova for a fee. In at least one clinic catering to a largely conservative Shi'ite clientele, some of these donors are young non-Muslim, American women who travel to Lebanon for extra payment to donate their eggs anonymously to infertile Lebanese couples. Ironically, those most likely to receive these "American eggs" are conservative Shi'ite couples, who accept the idea of donation because they follow the teachings of Ayatollah Khamanei in Iran. Thus, in Lebanon, those most likely to follow the spiritual guidance of Ayatollah Khamanei-and, hence, to receive American donor eggs-are generally members of or sympathizers with Lebanon's Hizbullah political 
party, which is officially described by the U.S. administration as a terrorist organization!

Furthermore, quite interestingly, in multisectarian Lebanon, the recipients of these donor eggs are not necessarily only Shi'ite Muslim couples. Some Sunni Muslim patients from Lebanon and from other Middle Eastern Muslim countries such as Egypt and Syria are quietly slipping across transnational borders to "save their marriages" through the use of donor gametes, thereby secretly "going against" the dictates of Sunni Muslim orthodoxy. Such border crossing has also been noted by Clarke (2006) for Lebanon; he writes, "Indeed patients come from other countries to benefit from this relatively relaxed regime" (26). The same is true in Iran, where, according to IVF clinic staff, scores of Persian Gulf Arabs from countries such as Saudi Arabia and Kuwait are traveling to Tehran in pursuit of donor gametes.

\section{CONCLUSION}

In conclusion, it is fair to state that global reproductive "technoscapes" (Appadurai 1996) are becoming increasingly expansive as we enter this new millennium. As this article has tried to show, the Muslim world - generally positioned on the receiving end of global reproductive technology transfers-has nonetheless embraced assisted reproductive technologies with considerable enthusiasm while, at the same time, reconfiguring them in accordance with the local religious moralities so important in this region.

Although generally portrayed as monolithic, Islam itself takes several different forms, as evident in this essay. In the Sunni Muslim world, which includes most Middle Eastern countries, the use of IVF and related assisted reproductive technologies has clearly led to an entrenchment of deeply held religious beliefs about the importance of biologically based kinship, family life, and parenthood. Yet the globalization of these technologies to the Shi'ite Muslim world has fundamentally altered understandings of the ways in which families can be made and the ways in which marriages can be saved through the uses of assisted reproductive technologies.

For Shi'ite Muslims, in particular, the frankly adventurous attitude on the part of some Shi'ite religious leaders toward third-party donation has led to a potential transformation in gender relations among infertile Muslim couples. For example, in Lebanon, the recent Shi'ite fatwas allowing egg donation have been a great boon to marital relations. There, both fertile and infertile men with "reproductively elderly" wives are 
lining up at IVF clinics to accept the eggs of donor women. Furthermore, in multisectarian Lebanon, the recipients of donor gametes are not necessarily only Shi'ite Muslim couples, but include some Sunni Muslim and Christian couples as well.

In short, the arrival of donor technologies in the Muslim Middle East has led to a brave new world of reproductive possibility never imagined when these technologies were first introduced there nearly 20 years ago. These technologies have engendered (1) significant medical transnationalism and reproductive tourism; (2) mixing of gametes across ethnic, racial, and religious lines; and (3) the birth of thousands of ICSI and, now, donor babies to devout infertile Muslim couples. Infertile couples have begun to reconsider traditional notions of biological kinship, even if "social parenthood" of a donor child is still not widely embraced (Inhorn 2006b). And because donor technologies are now widely available in both Iran and Lebanon, the power of the Sunni Muslim ban on third-party donation is being weakened across the region, with some infertile Sunni Muslim couples reconsidering their own antidonation moral stances. As a result, Shi'ite gametes are finding their ways into Sunni bodies, an interesting variation on the "making of Muslim babies."

In my view, these multiple transformations are powerful indicators of the profound social effects that reproductive technologies may engender in the new world order. As the assisted reproductive technologies become further entrenched in the Muslim world, and additional forms of global reproductive technology become available, it is important to examine the new local moral worlds that are likely to arise in response to this variant of globalization. The pace of change evident in the production of assisted reproductive technologies themselves - as highlighted on the recent Nova special called "18 Ways to Make a Baby" - as well as the rapid spread of these technologies into far reaches of the non-Western world is, indeed, striking. Thus, as one science and technology studies scholar, David Hess (1994), rightly observes, "Anthropology brings to these discussions a reminder that the cultural construction of science is a global phenomenon, and that the ongoing dialogue of technoculture often takes its most interesting turns in areas of the world outside the developed West" (16).

\section{ACKNOWLEDGMENTS}

I want to express my gratitude to the numerous men and women in both Egypt and Lebanon who spoke to me about their infertility and IVF experiences. The IVF physicians, nurses, and staff members who helped me 
to recruit patients into my IVF studies deserve great credit; they include (in alphabetical order) Antoine Abu Musa, Johnny Awwad, Abbass Fakih, Michael Hassan Fakih, Walid Ghutmi, Najwa Hammoud, Antoine Hannoun, Azhar Ismail, Da'ad Lakkis, Zaher Nassar, Khaled Sakhel, Gamal Serour, Hanady Shrara, Mohamed Yehia, Salah Zaki, and Tony Zreik. I also want to thank my primary research assistants, Mary Ghanem and Tayseer Salem, as well as my colleagues at American University of Beirut, including Huda Zurayk and Rima Afifi, who so generously hosted me and provided an institutional affiliation. My intellectual soulmates, Aditya Bharadwaj and Soraya Tremayne, have been kindred spirits in this research on IVF and gamete donation in the non-Western world. This research was generously supported by the National Science Foundation and the U.S. Department of Education Fulbright-Hays Program.

\section{NOTES}

1. To overcome the difficulties of raising a biologically unrelated donor child, some Shi'ite physicians in Lebanon are arguing for a variety of novel solutions, including inheritance through gifts and bequests; institutions of rida' (milk kinship), whereby the mother of a donor child becomes related to it through breastfeeding; and the notion of legal guardianship of foster children (Clarke 2006).

2. I am deeply grateful to Soraya Tremayne, who, fresh from fieldwork in Iran, has engaged in a lively e-mail discussion with me and has provided invaluable information on the practices of IVF and gamete donation in Iran since 2004. I have tried to represent her findings as accurately as possible in this paper.

3. In Iran, I want to thank Mohammad Jalal Abassi-Shavazi, Mohamad Mehdi Akhondi, and Pegah Ebadi for so generously inviting and hosting me at the Avesina Research Center and University of Tehran conference on embryo and gamete donation.

4. In Lebanon, anonymous sperm donation - using frozen sperm from overseas sperm banks or fresh sperm samples from mostly medical and graduate students - is "quietly" practiced at IVF clinics. One of my azoospermic Lebanese male informants produced a donor child in this way, and several others, both Muslim and Christian, had also made the decision to use donor sperm.

5. In Iran, women commonly bring their sisters as potential egg donors. But this is not allowed, as Islam is explicitly against the marriage of one man to two living sisters. Apparently, men also bring their brothers as potential sperm donors in Iran. According to Tremayne, she observed one case where the husband did so without his wife's knowledge; the wife believed that she was receiving her husband's sperm instead of that of her brother-in-law.

6. Some leading members of the Lebanese medical community are pushing for a law that bans all forms of third-party donation in the country. However, this law has yet to be debated in the Lebanese parliament and is unlikely to pass, according to some sources. 


\section{REFERENCES}

Appadurai, Arjun

1996 Modernity at Large: Cultural Dimensions of Globalization. Minneapolis: University of Minnesota Press.

Clarke, Morgan

2006 Shiite Perspectives on Kinship and New Reproductive Technologies. ISIM Review 17: 26-27.

Cole, Juan

2002 Sacred Space and Holy War: The Politics, Culture and History of Shi'ite Islam. I. B. London: Tauris.

Freeman, Carla

2000 High Tech and High Heels in the Global Economy: Women, Work, and Pink-Collar Identities in the Caribbean. Durham, NC: Duke University Press.

Haeri, Shaela

1989 Law of Desire: Temporary Marriage in Shi'i Iran. Syracuse, NY: Syracuse University Press.

Hess, David

1994 Parallel Universes: Anthropology in the World of Technoscience. Anthropology Today 10: 16-18.

Inhorn, Marcia C.

1996 Infertility and Patriarchy: The Cultural Politics of Gender and Family Life in Egypt. Philadelphia: University of Pennsylvania Press.

2003a "The Local Babies, Global Science: Gender, Religion, and In Vitro Fertilization in Egypt. New York: Routledge.

2003b "The Worms Are Weak": Male Infertility and Patriarchal Paradoxes in Egypt. Men and Masculinities 5: 236-256.

2004 Middle Eastern Masculinities in the Age of New Reproductive Technologies: Male Infertility and Stigma in Egypt and Lebanon. Medical Anthropology Quarterly 18: 162-182.

2006a Fatwas and ARTs: IVF and Gamete Donation in Sunni v. Shi'a Islam. Journal of Gender, Race and Justice 9: 291-317.

2006b "He Won't Be My Son": Middle Eastern Muslim Men's Discourses of Adoption and Gamete Donation. Medical Anthropology Quarterly 20: 94-120.

Kahn, Susan Martha

2000 Reproducing Jews: A Cultural Account of Assisted Conception in Israel. Durham NC: Duke University Press.

Kleinman, Arthur

1995 Writing at the Margin: Discourse between Anthropology and Medicine. Berkeley: University of California Press.

2006 What Really Matters: Living a Moral Life amidst Uncertainty and Danger. New York: Oxford University Press.

Lane Sandra D., and Robert A. Rubinstein

1991 The Use of Fatwas in the Production of Reproductive Health Policy in Egypt. Paper presented at the 90th Annual Meeting of the American Anthropological Association, Chicago. 
Lock, Margaret

2002 Twice Dead: Organ Transplants and the Reinvention of Death. Berkeley: University of California Press.

Meirow, D., and J.G. Schenker

1997 The Current Status of Sperm Donation in Assisted Reproduction Technology: Ethical and Legal Considerations. Journal of Assisted Reproduction and Genetics 14: 133-138.

Population Reference Bureau

2004 World Population Data Sheet. Washington DC: Population Reference Bureau.

Rapp, Rayna

1999 Testing Women, Testing the Fetus: The Social Impact of Amniocentesis in America. New York: Routledge.

Serour, Gamal I.

1992 Medically Assisted Conception: Dilemma of Practice and Research-Islamic Views. In Proceedings of the First International Conference on Bioethics in Human Reproduction Research in the Muslim World. Gamal I. Serour, ed., pp. 234-242. Cairo: International Islamic Center for Population Studies and Research.

1994 Islam and the Four Principles. In Principles of Health Care Ethics. Raanan Gillon, ed., pp. 75-91. Chichester UK: John Wiley.

1996 Bioethics in Reproductive Health: A Muslim's Perspective. Middle East Fertility Society Journal 1: 30-35.

Serour, G.I., M.A. Aboulghar, and R.T. Mansour

1995 Bioethics in Medically Assisted Conception in the Muslim World. Journal of Assisted Reproduction and Genetics 12: 559-565.

Serour, G.I., M. El Ghar, and R.T. Mansour

1990 In Vitro Fertilization and Embryo Transfer: Ethical Aspects in Techniques in the Muslim World. Population Sciences 9: 45-54.

1991 Infertility: A Health Problem in the Muslim World. Population Sciences 10: $41-58$.

Serour, G.I., and A.R. Omran, eds.

1992 Ethical Guidelines for Human Reproduction Research in the Muslim World. Cairo: International Islamic Center for Population Studies and Research.

Sonbol, Amira el-Azhary

1995 Adoption in Islamic Society: A Historical Survey. In Children in the Muslim Middle East. Elizabeth W. Fernea, ed., pp. 45-67. Austin: University of Texas Press.

Tober, Diane M.

2004 Shi'ism, Pragmatism, and Modernity: Islamic Bioethics and Health Policy in the Islamic Republic of Iran. Paper presented at the University of Michigan, Ann Arbor.

Tremayne, Soraya

2005 The Moral, Ethical and Legal Implications of Egg, Sperm and Embryo Donation in Iran. Paper presented at the conference on Reproductive Disruptions: Childlessness, Adoption, and Other Reproductive Complexities, University of Michigan, Ann Arbor, May 19.

2006 Whither Kinship? New Assisted Reproduction Technology Practices, Authoritative Knowledge and Relatedness - Case Studies from Iran. Paper presented at the conference on Gamete and Embryo Donation, University of Tehran, Tehran, Iran, March 2. 
Zuhur, Sherifa

1992 Of Milk-Mothers and Sacred Bonds: Islam, Patriarchy, and New Reproductive Technologies. Creighton Law Review 25: 1725-1738.

\section{MARCIA C. INHORN}

Director, Center for Middle Eastern and North African Studies, Professor, Department of Health Behavior and Health Education, Program in Women's Studies, and Department of Anthropology University of Michigan Ann Arbor

$U S A$

Department of HBHE

School of Public Health II

University of Michigan

1420 Washington Heights

Ann Arbor, MI 48109-2029

USA

E-mail:minhorn@umich.edu 